\title{
Российские вооруженные силы в 2020 году: Россия на обратном пути к проецированию силы? Последствия для HATO
}

\author{
Томас Браун
}

\section{Введение}

«Россия потеряла свою армию». Этот заголовок редакционной статьи, опубликованной на портале о вооруженных силах и глобальной обороне DefenceTalk в октябре 2003 года, дает представление о восприятии ситуации российским военным руководством в начале двадцать первого века. ${ }^{1}$ Развитие событий после распада Советского Союза привело к множеству попыток реформировать российские вооруженные силы. В начале 1990-х бывший российский министр обороны Павел Грачев начал проводить некоторые военные реформы, но встретил сильное сопротивление среди русского офицерского корпуса (все еще находящегося под сильным влиянием советской эпохи), который пытался сохранить систему и свои позиции. ${ }^{2}$ Большинство последующих реформистских попыток в течении последних двадцати лет-которые, в общем-то, были ограничены сокращением живой силы и вооружений, без уделения внимания более широкой военной системе и организационной структуре-не добились достижения цели создания реструктурированных современных вооруженных сил. Это привело русского военного журналиста, Александра Гольца, к тому, чтобы в 2004 году опубликовать книгу Армия России: 11 nотерянных лет, в которой он делает вывод, что между 1993-м и 2004-м годами военные реформы, которые проводились в России, не имели ощутимых результатов. ${ }^{3}$ Чтобы справиться с отсутствием прогресса в реформировании вооруженных сил, новоназначенный гражданский министр обороны Анатолий Сердюков 23 февраля 2008 года представил свою концепцию, так называемый «Новый взгляд». Приведут ли реформы «Нового взгляда» к «новому восходу Красной Звез-

\footnotetext{
Майор Томас Браун, дипломированный педагог, офицер военно-воздушных сил, проходил службу на Балканах и в Судане. Он выпускник Центра им. Джорджа К. Маршалла, закончил немецкий командно-штабной колледж. Сейчас Томас Браун работает в офисе военного представителя Германии в Военном комитете НАТО в штаб-квартире НАТО в Брюсселе. Как член Военного подготовительного комитета (ВПК) военных представителей в Совете НАТО-Россия, он причастен к будущему развитию отношений НАТОРоссия. Дополнительно его исследования сфокусированы на развитии способностей НАТО и на всех столбах Общих ресурсов НАТО. Точка зрения, представленная в этой статье, является личным мнением автора.

1 "Russia Has Lost its Army," DefenceTalk (21 October 2003); доступно на: www.defencetalk.com/russia-has-lost-itsarmy-1384.

2 Timothy L. Thomas, Recasting the Red Star: Russia Forges Tradition and Technology through Toughness (Fort Leavenworth, KS: Foreign Military Studies Office, 2011), 11.

3 Там же.
} 
ды», символа бывшей Советской армии? Каковы возможные последствия такого возрождения для НАТО? Чтобы понять императивы, стоящие за «Новым взглядом» Сердюкова, необходимо понять, в чем состоят национальные интересы России, так как каждое правительство рассчитывает свои военные реформы на основе своих национальных интересов, а так же на основании идентифицированных угроз и рисков.

\section{Ключевые аспекты российской внешней политики}

После распада Советского Союза российские национальные интересы в принципе не изменились, за одним исключением. Значение экономического процветания, связанное с нефтью, природным газом и другими ископаемыми ресурсами, сильно увеличилось, так как это богатство воспринимается как основа любой попытки справиться с существующими и будущими внутренними проблемами, а так же и как средство вернуть влияние России на так называемое «ближнее зарубежье». Традиционные национальные интересы России, которые заявлены в Концепции внешней политики от июля 2008 года и Национальной стратегии безопасности от 2009 года, включают укрепление демографического здоровья и безопасности, а так же обеспечение безопасности на ее границах и в близком зарубежье. Дополнительно к этому, Россия хочет обеспечить то, что она останется основным актором в регионе, и в особенности в Центральной Азии. ${ }^{5}$ Недавно опубликованная «Новая военная доктрина» от февраля 2010 года ссылается на значение «ближнего зарубежья» и подчеркивает озабоченность России наступлением НАТО на этот регион. Чтобы гарантировать региональное влияние России и чтобы защитить русские интересы, российские вооруженные силы, в соответствии с этой доктриной, «оперативно могут быть использованы вне территории России» в одностороннем порядке. ${ }^{6}$ Похоже, Россия предпочитает дислоцировать свои вооруженные силы за границу в рамках механизмов Организации договора о коллективной безопасности. ${ }^{7}$ Российские национальные интересы и их отражение в Новой военной доктрине, так же как и текущий упор на «ближнее зарубежье», следует учитывать при анализе любых действий, направленных на реформирование российских вооруженных сил.

4 «Ближнее зарубежье» включает Белоруссию, Украину, Грузию, Азербайджан, Туркменистан, Узбекистан и Таджикистан. Смотри: David Capezza, "Translating Russia's Military Reform,” Small Wars Journal (2009): 3; доступно на: http://smallwarsjournal.com/jrnl/art/ translating-russias-military-reform.

5 Там же.

6 Marcel de Haas, "Russia's Military Doctrine Development," в Russian Military Politics and Russia's 2010 Defense Doctrine, под ред. Steven Blank (Carlisle, PA: Strategic Studies Institute, U.S. Army War College, 2010), 42.

7 Там же, 45. 


\section{После «Крушения Красной Армии»: вооруженные силы России в начале двадцать первого века}

«Никогда с 1941 года российские вооруженные силы не были так угрожающе близко к краху, как сейчас» заявил доктор Алексей Арбатов, заместитель председателя Комитета по обороне в Госдуме в 1998 году. ${ }^{8}$ В начале двадцать первого века российские вооруженные силы-которые унаследовали большую часть Советской Красной армии в смысле солдат и вооружений,-все еще боролись с наследием, обусловленным ментальностью советской эпохи, и с наследством устаревшего оборудования. Первый пересмотр российской военной доктрины, проведенный в 1993 году, был в целом неуспешным в реорганизации вооруженных сил и в изменении старой советской военной ментальности; российские силы были разбросаны на обширной территории всего бывшего Советского Союза без общей стратегии и организации. ${ }^{9}$ Хотя проигранная кампания в Чечне во время первой чеченской войны 1994-96 (так же как и гибельная атака на Грозный в 2004 году) и помогли сделать заметным недостаточную подготовку и натренированность русской армии. Это привело ко многим попыткам провести реформы, но все они были неуспешными. Российское правительство преуспело в сокращении численности вооруженных сил, но целостная структура вооруженных сил осталась с непропорционально большой верхней частью, недостаточно натренированной и плохо мотивированной. В соответствии с руководящей целью ограничить расходы при сохранении достаточных сил для сдерживания потенциальных агрессоров, Россия уменьшила численность своих вооруженных сил от почти 3 миллионов в 1991 году до 1.1 миллиона в 2008, хотя последний круг существенных сокращений имел место в 1999 году. ${ }^{10} \mathrm{C}$ тех пор призывы к дальнейшим сокращениям игнорировались. Более того, внутреннее функционирование российской армии находилось под влиянием массовой коррупции, и система, известная как дедовщина, неофициальная система подавления молодых призывников старыми солдатами (по существу формализованное злобное издевательство над новичками), все еще существует и сегодня. ${ }^{11}$ Растущая коррупция заставила премьера Путина в 2003 году заняться борьбой с коррупцией как одним из главных приоритетов в воссоздании российских вооруженных сил. ${ }^{12}$ Проблемы, которые были упомянуты, были характерными для внутреннего состояния военного аппарата. В 2012 году была открыта публичная веб-страница для официальных жалоб внутри российских вооруженных

8 Alexei G. Arbatov, "Military Reform in Russia: Dilemmas, Obstacles, and Prospects," International Security 22:4 (Spring 1998): 83.

9

10 Capezza, "Translating Russia's Military Reform," 6.

Там же, 9.

11 Dedovshchina is literally translated as the "grandfather rule." Kris D. Beasly, "Russian Military Reform from Perestroika to Putin: Implications for U.S. Policy," research paper prepared at Air University, Maxwell AFB, Alabama (April 2004), 79; доступно на: www.dtic.mil/cgibin/GetTRDoc?AD=ADA427322.

12 Там же, 54-55. 
сил. В дополнении к этим внутренним проблемам совершенно устарело вооружение и подготовка велась все более трудно. Хотя Путин приказал возобновить патрулирование стратегических бомбардировщиков, более половины всех воздушных ресурсов российских военно-воздушных сил не поддерживались и не были в состоянии боеготовности. В 2000 году средний налет русских летчиков составлял 12 часов в год, и был увеличен до 40 часов в 2007 году, но это абсолютно минимальный уровень, который необходим для обеспечения боевой готовности. ${ }^{13}$ Российский военно-морской флот столкнулся с теми же проблемами. В 2008 году были приостановлены все морские операции кроме берегового патрулирования, чтобы экономить горючее. Российско-грузинская война в августе 2008 года высветила множество проблем, связанных с личным составом, вооружением, организационной структурой и даже с правилами подготовки, которые не обновлялись аж с 1980 года. ${ }^{14}$ Несмотря на победу России в войне с Грузией, кампания оценивалась как катастрофа для вооруженных сил России, у которых не было объединенного командования, достаточной ситуационной осведомленности и они даже понесли тяжелые потери в военно-воздушных силах от своего собственного огня. ${ }^{15}$ Один русский офицер охарактеризовал российско-грузинскую войну следующим образом: «Вышло так, что в бой пошла не [русская] армия двадцать первого века - это была советская армия со схемами от 1960-х и 1980-х годов прошлого века». ${ }^{16}$

\section{«Новый взгляд»: русские военные реформы 2008 года}

Отсутствие новой военной доктрины в 2008 году после российско-грузинской войны, отсутствие публичного обсуждения вопросов национальной безопасности и диапазон ответственности российских вооруженных сил породили дискуссии, необходимы ли подлинные реформы в сфере обороны. Вице-президент ассоциации российских дипломатов, Андрей Бакланов, ясно выразил свои сомнения относительно необходимости в реформах, заявив в 2009 году: «Я не вижу никаких оснований для проведения таких реформ». ${ }^{17}$ На тот случай, если его неправильно поняли, он дополнил: «Большинство причин для неудовлетворительного состояния вооруженных сил ... не имеет ничего общего с отсутствием реформ». ${ }^{18}$ Редактор журнала Russian Politics and Law признал значимость перспективы первого подлинного случая реформирования оборонного сектора со времен распада Совет-

13 Capezza, "Translating Russia's Military Reform," 11.

14 Dale R. Herspring, "Is Military Reform in Russia for 'Real'? Yes, but...," в The Russian Military Today and Tomorrow: Essays in Memory of Mary Fitzgerald, под ред. Steven Blank, Richard Weitz (Carlisle, PA: Strategic Studies Institute, U.S. Army War College, July 2010), 153.

15 Там же, 152-54.

16 Там же, 155.

17 Независимое военное обозрение (перевод стенограммы круглого стола), "Urgent Problems and the Logic of Military Reform," [«Актуальные проблемы и логика военной реформы»] Russian Politics and Law 48:3 (May-June 2010): 59.

18 Там же, 59. 
ского Союза и подтвердил серьезность такого проекта. В феврале 2007 года президент Владимир Путин назначил штатского Анатолия Сердюкова новым министром обороны России. В первый раз со времени распада Советского Союза гражданское лицо стало министром обороны. Сердюков, как и Путин, родом из СанктПетербурга и его поддерживал как премьер-министр Медведев, так и президент Путин, который возложил на Сердюкова обязанность бороться с коррупцией и неэффективностью в вооруженных силах. ${ }^{19}$ Без всякого предварительного предупреждения в октябре 2008 года он начал проводить ряд преобразований, названных «Новым взглядом», старательно избегая спорный термин «реформы», хотя термин «Военная реформа 2008 года» широко используется. Российско-грузинская война определенно сработала катализатором введения «Нового взгляда», который считается наиболее радикальным системным изменением в российских вооруженных силах со времени «реформ, начатых Дмитрием Милютиным во второй половине девятнадцатого века». ${ }^{20}$

В плане Сердюкова «Новый взгляд» был объявлен широкий спектр изменений, который включал четыре ключевые измерения преобразований: ${ }^{21}$

1. Реструктурирование офицерского корпуса. При отношении офицеры/ контрактники 3:1 в российских вооруженных силах было необходимо уменьшить число офицеров от 355000 до $150000 .^{22}$ Большинство лишних офицеров служили в так называемых «кадрированных частях», которые не были в состоянии оперативной готовности и укомплектовывались людьми только в случае мобилизации. Кроме уменьшения числа офицеров всех рангов, за исключением лейтенантов, в реформе предлагалось учреждение корпуса профессиональных сержантов, который к тому времени не существовал в российских вооруженных силах. Создание корпуса профессиональных сержантов противодействовало бы системе дедовщчины и подняло бы уровень профессионализма в армии, так как опыт на уровне отделения и взвода сохранялся бы в вооруженных силах дольше, чем в прошлом.

2. Реорганизация структуры системы командования и управления. Российско-грузинская война показала отсутствие гибкости и единства командования в вооруженных силах России. Поэтому реформы «Новый взгляд» включали реорганизацию четырехуровневой командной структуры (военный округ - армия - дивизия - полк) в более гибкую и устойчивую трехуровневую модель (военный округ - оперативное командование - бри-

19 Thomas, Recasting the Red Star, 11-12.

20 Ilya Kramnik, "Military Reform: Basic Guidelines," RIA Novosti (24 February 2010); доступно на: http://en.rian.ru/analysis/20100224/157995299.html.

21 Pavel K. Baev, "Military Reform Against Heavy Odds," в Russia After the Global Economic Crisis, под ред. Anders Aslund, Sergei Guriev, Andrew Kuchins (Washington, D.C.: Peterson Institute for Internal Economics, May 2010), 170-72.

Herspring, "Is Military Reform in Russia for 'Real'?," 160. 
гада), в которой командующим военными округами вверено командование всеми частями в их зоне ответственности за исключением Ракетных войск стратегического назначения. Как независимое тактическое формирование, бригада предоставляет больше гибкости и требует меньше внешней поддержки в операциях. ${ }^{23}$

3. Ликвидация «кадрированньх частей». Упразднение частей сокращенного состава-так называемых «кадрированных частей»-подразумевает конец массовой мобилизации. Хотя некоторые аспекты планов мобилизации сохранятся, такие как объекты хранения вооружений и оборудования, число военных формирований будет уменьшено от 1890 до 172, все они будут полностью укомплектованы профессиональными солдатами и будут называться «части постоянной боевой готовности». ${ }^{24}$ Согласно «Новому взгляду» Сердюкова, из 22000 танков, ранее находящихся в российских сухопутных войсках, в оперативной готовности останутся только 2000.

4. Реорганизация системы военного образования. Учет уменьшения численности личного состава и высокой степени дублирования функций в вооруженных силах России привели к решению укрупнить российские военные образовательные институции. К 2013 году Сердюков решил уменьшить число военных образовательных центров от шестидесяти пяти разнотипных институций до десяти: три объединенных центра, шесть академий и один военный университет. ${ }^{25}$

В дополнение к этим четырем основным направлениям, Сердюков так же принял решение, что общая численность российской армии будет уменьшена до одного миллиона военнослужащих к 2013 году, а не к 2016, как первоначально планировалось. ${ }^{26}$ Параллельно с планом «Новый взгляд» была ускорена программа модернизации вооружений, так как в течении пятнадцати лет с начала процесса реформ в российской армии не была введена ни одна новая оружейная система. ${ }^{27}$ В 2008 году только 10 процентов военного оборудования российских вооруженных сил можно было считать «современным»; была поставлена цель поднять эту долю до 30 процентов к 2015 году. ${ }^{28}$ Для достижения этой цели Государственной Программе Перевооружения (ГПП) были обещаны 704.9 миллиардов долларов США в период с 2011 года до 2020 год для модернизации вооружений, которыми

\footnotetext{
Там же, 165.

Baev, "Military Reform Against Heavy Odds," 170.

Herspring, "Is Military Reform in Russia for 'Real'?," 161.

26 Steven Blank, ed., Russian Military Politics and Russia's 2010 Defense Doctrine (Carlisle, PA: Strategic Studies Institute, U.S. Army War College, 2010), 166.

27 Ilya Kramnik, "Russian Military Reform in Times of Crisis," RIA Novosti (15 March 2010); доступно на: www.defencetalk.com/russian-military-reform-in-times-of-crisis-24920.

28 Pavel K. Baev, "Russian Military Perestroika," в U.S. Europe Analysis, no. 45 (Brookings Institution Center on the United States and Europe, 29 April 2010), 3.
} 
оснащена российская армия. ${ }^{29}$ Большая часть этих средств будет использована на модернизацию стратегических ядерных сил страны, которые считаются гарантом безопасности России, затем на инвестиции в космические системы оружия и в противовоздушную оборону. Дополнительное внимание будет уделено сфере коммуникаций, командования и управления, и стратегической мобильности.

\section{Вызовы и успехи военной реформы в 2011 году}

Реакция высших офицеров на план Сердюкова «Новый взгляд» была резко отрицательной. Как отметил один исследователь, «все трех- и четырехзвездные генералы на ключевых административных постах либо вышли в отставку, либо были уволены». ${ }^{30}$ Сопротивление радикальным изменениям, инициированным министром Сердюковым, было очень сильным, но несмотря на противодействие со стороны высшего военного руководства и в самой администрации, по всем проектам был отмечен достаточный прогресс, так что «точка невозврата» была пройдена в 2010 году. В публичном пространстве появились разнонаправленные комментарии, касающиеся статуса и успеха этих реформ. В частности, высшие военные руководители и верховное политическое руководство, похоже, по разному понимали прогресс реформ. Последние назначения Командующих видов вооруженных сил (Сухопутных войск, Военно-воздушных сил и Военно-морского флота) были ясным знаком в пользу реформ, так как все новые командующие поддерживали линию действий Сердюкова. В октябре 2011 года министр обороны Сердюков отрапортовал, что первый этап реформ - который в основном касался организационных изменений и упразднения кадрированных частей - «близился к завершению». Далее он объявил переход от переструктурирования к перевооружению. ${ }^{31}$ Но его оценка не соответствует серьезности ряда проблем, касающихся основных направлений реформ, которые были упомянуты выше:

1. Реструктурирование офииерского корпуса и создание корпуса профессиональных сержантов. План «Новый взгляд» сталкивается с огромными проблемами, так как набор курсантов в военные школы был приостановлен на два года. ${ }^{32}$ Но не только набор курсантов подвергался риску. Игорь Баринов, заместитель председателя комитета по обороне в Думе, подтвердил, что в 2011 году новые строевые бригады были укомплектованы только на 75 процентов. Он заявил, что недобор обусловлен отсутствием

29 Forecast International, "Three Key Factors at Play for Russian Modernization,” DefenceTalk (14 April 2011); доступно на www.defencetalk.com/three-key-factors-at-play-for-russianmodernization-33469.

30 Herspring, "Is Military Reform in Russia for 'Real'?," 168.

31 Roger McDermott, "Serdyukov Signals 'First Stage' in 'Military Reform' Nearing Completion," Eurasia Daily Monitor 8:191 (18 October 2011); доступно на: www.jamestown.org/ single/?no_cache=1\&tx_ttnews\%5Btt_news\%5D=38541\&tx_ttnews\%5BbackPid\%5D=512.

32 Roger McDermott, "Russian Military 'New Look' Hovers in Limbo," Eurasia Daily Monitor 8:206 (8 November 2011); доступно на: http://www.jamestown.org/single/?no_cache=1\&tx_ ttnews\%5Btt_news\%5D=38639\&tx_ttnews\%5BbackPid\%5D=512. 
привлекательности карьеры в российских вооруженных силах, что и является причиной неуспеха в рекрутировании достаточного числа солдатов на контрактной основе. ${ }^{33}$ Частично непривлекательность военной карьеры является результатом неспособности полностью освободиться от системы дедовщиныл, ${ }^{34}$ и неспособности создать профессиональный сержантский корпус, что хорошо показали учения ВОСТОК 2010, где нехватка подготовленных сержантов была очевидной. ${ }^{35}$ Программа откладывается, так как необходимое, по оценкам, число кандидатов на сержантов-контрактников невозможно набрать из-за низкого уровня образования и плохого здоровья многих кандидатов. Целью является отбор 250000 кандидатов в корпус профессиональных сержантов, и похоже, имеются серьезные проблемы в привлечении достаточно квалифицированных и заинтересованных кандидатов. ${ }^{36}$ Другая проблема проистекает из массового увольнения офицеров, являющимися профессионалами, годными к быстрому развертыванию. Это развитие событий привело к ускоренному снижению боевой готовности и мотивации такого масштаба, что генерал-майор (в отставке) Павел Золотарев, заместитель директора Института США и Канады Российской академии наук, заявил, что вооруженные силы России на настоящий момент в действительности не готовы к широкомасштабной операции. ${ }^{37}$ И последнее, реформы воспринимаются как вызов военному менталитету, основанному на традиции, которую «Новый взгляд» разрушил до такой степени, что «офицерский корпус России находится в состоянии хаоса». 38

2. Реорганизаџия системы командования и управления. Одним из главных недостатков российских вооруженных сил, которые обнаружились в период российско-грузинской войны, было отсутствие эффективного командования и контроля. Реформы «Новый взгляд» привели к унификации систем командования и управления. Отдельные рода войск отказались от своих индивидуальных систем в пользу координированной, эффективной, экономящей время, унифицированной системы, позволяющей более на-

3 Там же.

34 Российское министерство обороны докладывало о 1700 случаях дедовщины с января по сентябрь 2010 года. Хотя это число ужасающе, оно по крайней мере показывает, что Министерство обороны России в конце концов обратило внимание на эту проблему. В 2003 году на вопрос о таких случаях, как лишение пищи молодых солдат и плохое питание, заместитель министра обороны В. Исаков просто отрицал существование таких проблем.

35 Thomas, Recasting the Red Star, 20.

36 Herspring, "Is Military Reform in Russia for 'Real'?," 171.

37 Независимое военное обозрение, «Актуальные проблемы и логика военной реформы», c. 90 .

38 Herspring, "Is Military Reform in Russia for 'Real'?," 168, 173. 
лаженное принятие решений. ${ }^{39} \mathrm{~B}$ дополнение к новой трехуровневой сфокусированной на бригаде структуре была введена автоматизированная система командования и управления, хотя она пока еще не достигла полной оперативной готовности. Эта часть реформы была завершена успешно потому, что как докладывал Сердюков 1 декабря 2009 года, восемьдесят пять строевых бригад могут быть развернуты в четырех заново организованных военных округах. ${ }^{40}$

3. Упразднение кадрированных частей и соединений. Число военных формирований в Сухопутных войсках России было уменьшено на 90 процентов, Военно-воздушных сил - на 48 процентов, Военно-морского флота - на 49 процентов и Ракетных войск стратегического назначения - на 33 процента. ${ }^{41}$ Одновременно с уменьшением размеров регулярных вооруженных сил развертывается программа модернизации, чья цель - достичь уровня оснащенности, при котором доля современных вооружений будет составлять 70 процентов к 2020 году, хотя в будущем надо будет учитывать существование ограничений, связанных с бюджетной ситуацией, особенно вследствие падения цен на нефть. Это радикальное сокращение числа частей и соединений было закончено в 2010 году и оно обозначило конец планов массовой мобилизации советской эпохи. ${ }^{42}$

4. Реорганизация системы военного образования. Реорганизованная образовательная система российской армии будет иметь значительно меньше объединенных академий и училищ, но к 2013 году должна показать лучшую координацию между институциями и оптимизированные учебные программы. Академия генерального штаба потеряла восемнадцать академических должностей, и в 2009 году приняла только шестнадцать офицеров, тогда как в 2008 году прием составлял сто офицеров. Фокус учебных программ сместился в сторону практического обучения и от офицеров требуется изучение иностранного языка. ${ }^{43}$ Система военного образования потребует и дальнейшего внимания, так как комплексный характер современных кризисных ситуаций сделает необходимой даже еще более широкую фундаментальную образованность офицеров.

Имея ввиду вышеупомянутые результаты, ожидалось, что уровень боевой готовности повысится благодаря предполагаемому профессионализму солдатов-контрактников, которые (как надеялись) будут оставаться в вооруженных силах на более длительный период. К середине 2011 года число солдатов по контракту со-

39 Thomas, Recasting the Red Star, 14.

40 Там же, 14-15.

41 Blank, Russian Military Politics and Russia's 2010 Defense Doctrine, 171.

42 Pavel Felgenhauer, "Rearmament Declared the Main Issue in Russian Military Reform," Eurasia Daily Monitor 7:122 (24 June 2010); доступно на: www.jamestown.org/single/?no cache $=1 \&$ tx ttnews $\% 5$ Btt news $\% 5 \mathrm{D}=36521$.

43 Thomas, Recasting the Red Star, 16. 
ставляло 180 000, и предполагалось, что к 2017 году оно вырастет до 425000 .4 $^{44}$ Чтобы увеличить набор рекрутов, с 1 января 2012 года была повышена зарплата с целью сделать службу в армии более привлекательной. Каков будет результат, еще предстоит увидеть. Дополнительно к этому будет повышен уровень социальных и жилищных условий военнослужащих. Но Россия сталкивается с дополнительными невоенными проблемами, связанными с будущим демографическим развитием и состоянием здоровья населения. Демографический дисбаланс в России, чье население быстро стареет, приведет к тому, что неоткуда будет набирать потенциальных рекрутов. $^{45}$ В 2011 в армию поступили всего 135000 призывников, вместо необходимых 250 - 300 000, что заставило начальника русского генерального штаба, генерала Николая Макарова, заявить: «Некого больше призывать». ${ }^{46}$ Все это определенно будет влиять на численность вооруженных сил и общую численность, вероятно, придется пересмотреть, уменьшив ее до 600 - 700000 военнослужащих. Что касается количества и качества оружия, находящегося в распоряжении русской армии, военно-промышленный комплекс в России не в состоянии удовлетворить потребности вооруженных сил, что привело к тому, что Россия начала покупать иностранное военное оборудование, такое как приборы ночного видения и вертолетоносцы типа «Мистраль» у Франции, или возможно, дополнительную броню для боевых машин у Германии. ${ }^{47}$ Другой факт, который надо учитывать в области вооружений, это расширяющееся быстрыми темпами сотрудничество с Индией, которая становится стратегическим партнером. ${ }^{48}$

Так как российскому военно-промышленному комплексу необходимо больше времени на осуществление перехода, ожидается, что количество закупаемого за границей вооружения для модернизации российских вооруженных сил будет увеличиваться. Был достигнут больший прогресс, чем ожидалось, но перед военной реформой в России стоят множество проблем, и риски фрагментации усилий очевидны. Уровень боевой готовности русской армии с начала реформ «Новый взгляд» понизился. Хотя этот спад, вероятнее всего, проистекает от характера переходного этапа реформ и не может быть вменен в вину самой программе «Новый взгляд», тем не менее преодолеть его в ближайшем будущем будет невозможно.

44 "Senior Russian Army Officers Resign over Military Reforms - Paper," RIA Novosti (5 July 2011); доступно на: http://en.rian.ru/mlitary_news/20110705/165026894.html.

45 Согласно РИА Новости, только 11.7 процентов молодых мужчин возраста 18-27 лет пригодны для службы в армии. Смотри: "Russian Military Has 'No one left to draft'," RIA Novosti (17 November 2011); доступно на: http://en.rian.ru/mlitary_news/20111117/ 168776056.html.

46 Там же.

47 Felgenhauer, "Rearmament Declared the Main Issue in Russian Military Reform."

48 "Medwedew lobt Beziehungen mit Indien als privilegierte Partnerschaft" [Медведев похвалил отношения с Индией в качестве привилегированного партнерства], РИА Новости (16 декабря 2011); доступно на http://de.rian.ru/politics/20111216/ 262019506.html. 


\section{Последствия для НАТО}

Новая военная доктрина от 2010 года свидетельствует, что российское стратегическое сообщество (по крайней мере авторы доктрины) не желают отказаться от идеи широкомасштабного конфликта с НАТО. Но когда они сталкиваются с реальностью, становится резко очевидным, что вследствие упразднения кадрированных частей исчезнет механизм российской армии для массовой мобилизации, что подразумевает отказ от идеи вести длительную конвенциональную войну. ${ }^{49}$ Косвенно это означает, что идея конвенциональной конфронтации с НАТО не является вероятным вариантом. И все усилия и успехи-так же как и вызовы,-в сфере военной реформы до сих пор подчеркивают факт, что Россия так же отказывается от возможности мобилизации в масштабе, который будет необходим для противодействия нападению, совершенному НАТО. Сегодняшние вооруженные силы России не являются прямой угрозой для НАТО, но они все еще располагают большими запасами субстратегических ядерных боеприпасов, чье наличие надо учитывать. Планируемый экспедиционный характер новых российских вооруженных сил открывает новые возможности для совместных миссий, таких как поддержание мира и продолжительные анти-пиратские операции. Среди задач Совета НАТО-Россия (СНР), который был учрежден в 2002 году, эти аспекты являются ключевыми областями сотрудничества между НАТО и Россией. Сотрудничество между военными НАТО и России сконцентрировано на возможных будущих совместных военных операциях. Первое участие российских военно-морских средств в операции НАТО «Активное усилие» в 2006/2007 году сразу же показало выгоду от сотрудничества с Россией. Имея в виду фокусирование российской внешней политики на «ближнее зарубежье», остается важным уважительно относиться к России как к ценному партнеру в обеспечении безопасности Центральной Азии, особенно учитывая наличие боевых бригад быстрого реагирования, которые Россия скоро приведет в боевую готовность. Реформы, начатые министром обороны Сердюковым, дали возможность укрепить отношения между НАТО и Россией, так как России, возможно, понадобятся дополнительные советы как продолжить свои реформы, хотя за последний год в диалог НАТО-Россия вернулся более полемический тон, что может быть результатом подготовки к последним президентским выборам в мае 2012 года. ${ }^{50}$ Однако, военная реформа является концепцией, которая имеет более широкое применение, чем только в отношении вооруженных сил, так что НАТО может предложить свой опыт в сфере военных поставок, что частично имело место в СНР и могло бы стать существенной частью ежегодного Рабочего плана, который структурирует сотрудничество НАТО и России. Как подтвердил первый заместитель министра обороны Поповкин в 2008 году, «современное военное оборудование настолько сложно, что нам понадобится ино-

49 Baev, "Russian Military Perestroika," 2.

50 "Medvedev's Missile Shield Remarks May Be Election Rhetoric - NATO Chief," RIA Novosti (8 December 2011); доступно на: http://en.rian.ru/world/20111208/169468939.html. 
странное ноу-хау в процессе наших собственных военных исследованиях». ${ }^{51}$ Очевидно, это заявление может означать расширение потенциальных областей сотрудничества после завершения исследования от 2007 года «Сотрудничество НАТО-Россия в сфере военного производства, исследований и технологий». ${ }^{5}$ Это так же является возможностью повысить уровень совместимости через программы двухстороннего сотрудничества, такие как те, что были договорены с британцами в июле 2012 года, ${ }^{53}$ или через совместные учения, такие как «Бдительные небеса $2011 »$, когда военные НАТО и России отрабатывали перехват угнанных пассажирских самолетов в рамках Комплексной аэрокосмической инициативы СНР. Чтобы НАТО имело выгоду от желания России модернизировать свой арсенал, НАТО обязано приветствовать поставку западных технологий и действовать как умножитель, предлагая содействие, и в то же время не пренебрегать своими интересами при трансфере технологий. И на последнем месте, горячая тема о противоракетной обороне могла бы стать сферой более широкого сотрудничества при возможной разработке совместных систем, что обеспечило бы реализацию доминированного НАТО и США подхода, в то же время позволяя России модернизировать свои оборонные системы, так как ядерный конфликт между Россией и НАТО маловероятен.

7 декабря 2011 года в финальном заявлении встречи Северо-Атлантического Совета (САС) в Брюсселе министры иностранных дел стран НАТО «еще раз подтвердили, что сотрудничество НАТО и России остается вопросом стратегический важности. ... Мы также причастны к укреплению доверия и прозрачности в сфере трансформации системы обороны, военных доктрин, военной стратегии, расположения войск и военных учений. Мы хотим видеть настоящее стратегическое партнерство между НАТО и Россией, и мы будем действовать соответствующим образом, надеясь на реципрокное отношение со стороны России». ${ }^{54}$ Все это ясно показывает, что НАТО хочет использовать СНР как удобный инструмент для сотрудничества с Россией и предлагает помощь и укрепление доверия, которые могут пригодиться министерству обороны России, если оно преодолеет устаревшее отношение к НАТО и примет поддержку в проведении военных реформ «Новый взгляд». С русской точки зрения важным является то, чтобы любая предлагаемая помощь была бы представлена как возможность, а не как попытка индоктринации. Если оперативная совместимость начнет приближаться к уровню стандартов НАТО и если политические препятствия останутся позади, НАТО может выиграть

51 Felgenhauer, "Rearmament Declared the Main Issue in Russian Military Reform," 3.

52 “Nato's relations with Russia” (June 2012); доступно на: http://www.nato.int/cps/en/natolive/ topics_50090.htm.

53 "Russia, Britain plan to improve military ties," RIA Novosti (19 July 2011); available at http://en.rian.ru/mlitary_news/20110719/165282948.html, http:/www.defencetalk.com/russia britain-plan-to-improve-military-ties-35777 (5 December 2011).

54 NATO, "Final statement of the meeting of the North Atlantic Council at the level of Foreign Ministers," held at NATO Headquarters, Brussels, on 7 December 2011; доступно на: http://www.nato.int/cps/en/natolive/official_texts_81943.htm?selectedLocale=en. 
от пересмотра своей позиции и оценит возможность того, чтобы Россия стала чемто большим, нежели специальным партнером, с возможным будущим вкладом в операции НАТО.

\section{Российские вооруженные силы в 2020 году: новый восход «Красной звезды» или «новый член НАТО»?}

«Сегодня у России нет ясной иерархии принятия и контроля стратегических решений», заявил один из участников дискуссий круглого стола о военной реформе в России в 2010 году. ${ }^{55}$ Однако министр обороны Сердюков предпринял некоторые шаги, вызванные новой сложной средой глобальной безопасности. В период кампании, предшествующей президентским выборам в 2012 году, тон дебатов стал более жестким и противоречия между новой Военной доктриной России, подписанной президентом Медведевым, и процессом военных реформ стали очевидными. Достигнутые успехи и результаты реформ «Новый взгляд» дают основание предположить, что будет построена более гибкая армия экспедиционного типа вооруженные силы, у которых меньше общего с целями военной доктрины России, чем с материальными и демографическими реалиями сегодняшней жизни в России. Чтобы понять русский подход к военным реформам, обязательно надо учитывать национальные интересы России. Сфокусированные на «ближнем зарубежье», результаты российских военных реформ создают для НАТО уникальную возможность искать пути к более практическому сотрудничеству и дают реальный шанс для углубления двухстороннего и многостороннего военного партнерства, особенно в Центральной Азии (при учете специальных интересов всех участвующих сторон). Пройдя через наиболее важные, может быть, за последние 150 лет реформы, российские вооруженные силы изменили все аспекты своей жизни. Процесс военных реформ начался медленно, но постепенно набирает скорость и уже может похвалиться некоторыми успехами, несмотря на остающиеся проблемы. Как заметил один наблюдатель, «в сравнении с другими военными реформами, начатыми после распада Советского Союза, эти реформы делаются по-настоящему». ${ }^{56}$ Продолжение мандата генерала Макарова в качестве Начальника обороны подчеркивает желание министра Сердюкова продолжить реализацию «Нового взгляда». Хотя Тимоти Томас предсказывал в 2010 году, что «переделка Красной звезды идет полным ходом», нынешнее развитие событий выглядит другим, не только потому, что изменились структура и руководящие положения, но и потому, что менталитет российских вооруженных сил вот-вот изменится кардинально. ${ }^{57} \mathrm{~B}$ ответ на вопрос, поставленный в начале заключительной части этой статьи, можно сказать, что протекающие сейчас военные реформы в России приведут не к «новому восходу Красной звезды», а к новой российской армии, кото-

55 Независимое военное обозрение, «Актуальные проблемы и логика военной реформы», 71.

56 Herspring, "Is Military Reform in Russia for 'Real'?," 151.

57 Thomas, Recasting the Red Star, 363. 
рая в ближайшем будущем будет в состоянии обеспечить национальные интересы России, кто бы ни угрожал им - снаружи или изнутри. Но у новых вооруженных силах России будет не только «Новый вид». Эти реформы расширят возможности России для сотрудничества и укрепления региональной безопасности, с наличием партнеров, или без них. Что касается угрозы, которые представляют Вооруженные силы России, министр обороны Эстонии, Март Лаар, отметил в сентябре 2011 года, что «Россия гораздо более опасна своей внутренней слабостью» и недавние манифестации русской оппозиции по всей стране подтверждают эту оценку. ${ }^{58}$

58 Agence France-Presse, "Russian Military Might Worries Region: Estonian General," DefenceTalk (26 September 2011); доступно на http://www.defencetalk.com/russian-militarymight-worries-region-estonian-general-37234 (15 November 2011). 


\section{Литература}

"Urgent Problems and the Logic of Military Reform." Russian Politics and Law 48, no. 3 (2010): 59.

Arbatov, Alexei G.. "Military Reform in Russia: Dilemmas, Obstacles, and Prospects." International Security 22, no. 4 (1998): 83.

Baev, Pavel K.. "Military Reform Against Heavy Odds." In Russia After the Global Economic Crisis, 170-72. Washington: Peterson Institute for Internal Economics, 2010.

Baev, Pavel K.. Russian Military Perestroika. Vol. 45 . U.S. Europe Analysis 45 . Brookings Institution Center on the United States and Europe, 2010.

Beasly, Kris D.. Russian Military Reform from Perestroika to Putin: Implications for U.S. Policy. Maxwell AFB Alabama: Air University, 2004.

Blank, Steven. Russian Military Politics and Russia's 2010 Defense Doctrine. Carlisle, PA:: Strategic Studies Institute, U.S. Army War College, 2010.

Capezza, David. "Translating Russia’s Military Reform." Small Wars Journal (2009).

de Haas, Marcel. "Russia's Military Doctrine Development." In Russian Military Politics and Russia's 2010 Defense Doctrine. Carlisle, PA: Strategic Studies Institute, U.S. Army War College, 2010.

Felgenhauer, Pavel. "Rearmament Declared the Main Issue in Russian Military Reform." Eurasia Daily Monitor 7, no. 122 (2010).

France-Presse, Agence. Russian Military Might Worries Region: Estonian General. DefenceTalk, 2011.

Herspring, Dale R.. "Is Military Reform in Russia for 'Real'? Yes, but ...." In The Russian Military Today and Tomorrow: Essays in Memory of Mary Fitzgerald, 153. Carlisle, PA: Strategic Studies Institute, U.S. Army War College, 2010.

Kramnik, Ilya. Military Reform: Basic Guidelines. RIA Novosti, 2010.

Kramnik, Ilya. Russian Military Reform in Times of Crisis. RIA Novosti, 2010.

McDermott, Roger. "Russian Military 'New Look' Hovers in Limbo." Eurasia Daily Monitor 8, no. 206 (2011).

McDermott, Roger. "Serdyukov Signals 'First Stage' in 'Military Reform' Nearing Completion." Eurasia Daily Monitor 8, no. 191 (2011).

Medvedev's Missile Shield Remarks May Be Election Rhetoric - NATO Chief. RIA Novosti, 2011. 
Medwedew lobt Beziehungen mit Indien als privilegierte Partnerschaft [Medvedev Praises Relationship with India as a Privileged Partnership]. RIA Novosti, 2011.

NATO. "Final statement of the meeting of the North Atlantic Council at the level of Foreign Ministers." Brussels: NATO Headquarters, 2011.

Russia Has Lost its Army. DefenceTalk, 2003.

Russia, Britain plan to improve military ties. RIA Novosti, 2011.

Russian Military Has 'No one left to draft'. RIA Novosti, 2011.

Senior Russian Army Officers Resign over Military Reforms - Paper. RIA Novosti, 2011.

Thomas, Timothy L.. Recasting the Red Star: Russia Forges Tradition and Technology through Toughness . Fort Leavenworth, KS: Foreign Military Studies Office, 2011.

Three Key Factors at Play for Russian Modernization. DefenceTalk, 2011. 